\title{
正極性雷インパルス電圧印加による気中 ギャップのコロナ放電進展過程と空間電荷
}

$\begin{array}{lllll}\text { 正員 山 本 } & & \text { 修 } & \text { (京都大) } \\ \text { 正員 河 野 } & \text { 俊 } & \text { 彦 } & \text { (京都大) } \\ \text { 正 員 上之園 } & \text { 親 } & \text { 佐 } & \text { (京都大) }\end{array}$

\section{1.まえがき}

気中・不平等電界江叔ける絶縁破坡は，コロナ放電 からリーダ，アークへと進展する。このコロナ放電に よってギャップに生成される空間電荷は，その後の放 電進展淁響を及活をされ，近年，ての空間電荷に 関する研究がなされてきた (1) (3)。

本研究では，校対平板電極に正極性雷インパルス電 圧を印加したときのコロナ放電により生成される空間 電荷量を，著者らが開発した静電誘導形プローブ法に より測定した。また，棒電極からギャップに放出され る放電電荷量を測定し，乙机之空間電荷量を比較した 結果から，空間電荷の振舞を明らかにした。静電誘導 形プローブ法は金属球からなるプローブをギャップ軸 加ら離して設置し，その誘導電流や誘導電荷から空間 電荷量などを測定するもので，詳細は文献（4）に述べ てある。コロナがギャップを橋絡し得ない程度のとき の放電電荷量上本プローブ法仙上る空間電荷量は一致 するが，コロナが発達するに従って両者は一致しなく なる。前者については上述の文献で述へており，こて では㣪者の実験結果について述へる。この実験結果に ついては光パルス，静止写真扔よび平板電極の表面電 界の測定により解析を行なった。またギャップ軸之 垂直または平行汇絶緑板を配置し，その沿面で得られ る電荷図の観察をも行なった。これらの成果について 以下に報告する。

The Development of Impulse Corona and the Behavior of its Space Charge of Rod-Plane Gaps in Air. By Osamu Yamamoto, Member, Toshihiko Kouno, Member \& Chikasa Uenosono, Member (Department of Electrical Engineering II, Kyoto University).

山本 修: 正買, 京都大学工学部裂氮工学第二教室

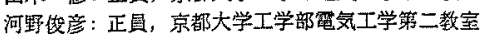

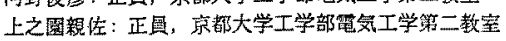

\section{2. 実験装置および実験方法}

本実験に用いた実験装置の概要を図 1 亿示す。雷イ ンパルス電圧発生装置の電王波形は，正極性（1.8 $\times 50)$ 到 である。供試電極は黄銅製の半球棒対平板電 極で，棒電極先端の曲率半徍は $0.5 \mathrm{~cm}$ である。この 棒電極は，放電電荷量の測定のため，先端の半球部を 絶縁した分割電極である。平板電極は直径 $1 \mathrm{~m}$ の円板 で, 後述のように，その表面の電界を測定するために 合計 8 個のプローブ $P_{E}$ が取付けてある。

空間電荷量の測定は静電誘導形プローブ法 (微分形) によった。図1中(1)がこのプローブ Prで,これは 半径が $0.5 \mathrm{~cm}$ の金属球であり, 空間電荷からの静電 誘導による電流を検出するための抵抗 $(75 \Omega)$ を通し て接地してある。プローブP，の配置はギャップの長 さgによって異なり、ギャップ軸からの距離を $g$ の 1.5 倍, 平板電極加らの高さを $g$ の 0.5 倍にとっ た。ここでは，乙のようなプロープP，の配置を標準 配置と呼引。

コロナ放電に伴い棒電極先端の半球電極加ら放電空 間に流れる電流 (以下, 分割電極の電流上呼ふ）を $i_{d}$,

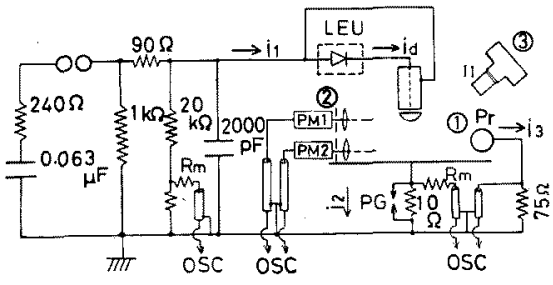

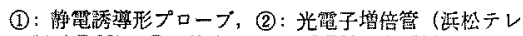

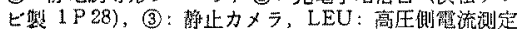

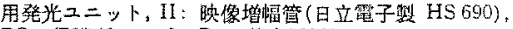
$\mathrm{PG}$ : 保葆ギャッブ， $R_{m}$ ：整合用抵抗

図 1 実験装置

Fig. 1. Experimental apparatus. 
平板笔極およびプローブP，から大地に流出する電流 をそれぞれ $i_{2}$ および污とする。また，半球電極から の放電電荷量学 $Q_{d}$, 平板電極加ら大地に流出する電

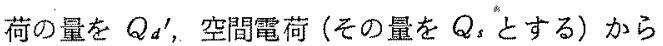
プローブ Pr K誘導する電荷の量を $q_{3}$ とすると, こ れらの電荷量は次式で示される。なお，との $i_{d}$ の測 定には図 1 のように発光ユニットを用いた。また， は電流検出用抵抗 $(10 \Omega)$ により测定した。

$$
\begin{aligned}
Q_{d} & =\int i_{d} d t \ldots \ldots \ldots \ldots \ldots \\
Q_{d} & =\int i_{2} d t \ldots \ldots \ldots \ldots . \\
Q_{s} & =A q_{3}=-A \int i_{3} d t
\end{aligned}
$$

ただし，(3)式のA は定数で, プローブP，の位置 上 $g$ の関数であり実験から求める。ギャップの長さ $g$ が 5, 7.5, 10, $15 \mathrm{~cm}$ に就い, 標準配置のプローブ P.に対するA はそれぞれ - 30 , -66, - 110 および ー180であった。ただし， $g$ が $5 \mathrm{~cm}$ のときの $A$ は $g \geqq 7.5 \mathrm{~cm}$ に和ける $A$ 亡gの関係直線(4)学外そうし て求めた。

图1中 (2)は放電時の光パルスを測定するための光 電子堌輻管 $\mathrm{PM}_{1}, \mathrm{PM}_{2}$ で，集光のためにいずれも石 英レンズとギャップの軸に垂直なスリットが取付けて ある。その視野は，ギャップ軸の位置で軸方向に 0.1 $\mathrm{cm}$, 軸上直角方向に $12.5 \mathrm{~cm}$ である。 $\mathrm{PM}_{1}$ は $i_{d}$, $i_{2}, i_{3}$ および $\mathrm{PM}_{2}$ の椡定用オシロスコープのトリガと して用い， $\mathrm{PM}_{2}$ はギャップ軸上の任意の位置の光パ ルスを測定するために用いる。また（3は放電像を撮 影するための静止カメラと映像增幅管 II である。

図2のように，表面電界測定用プローブ $P_{E}$ (図中 $P_{E 1} \sim P_{E 8}$ 之記す）は，いず机も直径 $0.5 \mathrm{~cm}$ の内板 で, 平板電極とこの円板との間げきは $0.1 \mathrm{~mm}$ であ

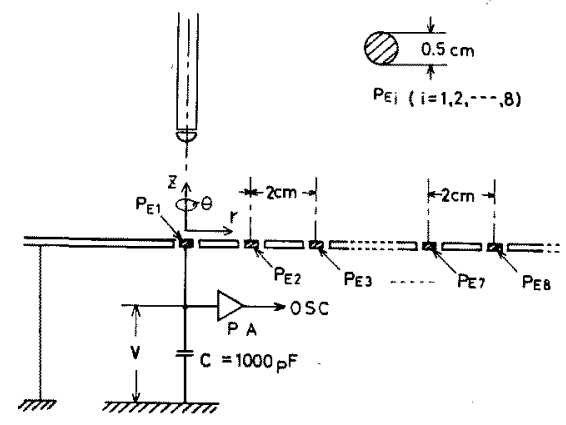

図 2 電界測定用プローブの説明

Fig. 2. Probes for measuring the electric field on the plane.
る。罒のように，平板電極の中心を原点，ギャップ軸 を $z$ 軸とした円筒座標系 $(r, \theta, z)$ で表わすと， $P_{E 1}$ は座標原点㯰き $P_{E 2} \sim P_{E 8}$ は $\theta=0$ の位置に $2 \mathrm{~cm}$ 間隔で一列に置いた。これらの各プローブのギャップ に対向した面の電界 $E$ は，同図のコンデンサ $C$ $(1,000 \mathrm{pF})$ 亡その誘導電圧 $V$, およびプローブ $P_{E}$ の表面皘 $S\left[=0.25^{2} \times \pi\left(\mathrm{cm}^{2}\right)\right]$ टから次式のように求 まる。

$$
E=C V / \varepsilon S
$$

ただし， $\varepsilon:$ 大気の誘電率

なお，誘導電王 $V$ 住図中に示す前置增幅器 PAを 通してオシロスコープに導いた。また，電界 $E$ の测 定時には $i_{2}$ 検出用抗 $(10 \Omega)$ は短絡し, プローブ Prは取除いた。逆に，泣の測定時には 8 個のプロー ブPEはすへて平板電極に短絡させた。

気中放電時の電荷図の測定には絶緣板（アクリル製 $35 \times 35 \mathrm{~cm}^{2}$, 厚さ $0.2 \mathrm{~cm}$ ) を用い，粉末として硫黄 (黄色) 乙酢酸鉛(白色)の湿合物を用いた。電荷図の極 性は，乙の色の違いから判別した ${ }^{(5) 。}$

本実験では，コロナ発生時間の不整を㧕制するた め, 初期電子供給用の紫外線ランプをギャップがら $1 \mathrm{~m}$ (ギャップの長さの6倍以上) の位置に圆いた。 の光量はランプの前面に設けた絞りによって調節で き，これによって発生時間の不整は $2 \sim 3 \mu \mathrm{s}$ となり, コロナは㽖加電仕の波高值付近で発生させるこよがて きた。従って，ここではコロナ発生瞬時電压として印 加電王の波高值をとるととにした。

\section{3. 実験 結果}

\section{$\langle 3 \cdot 1\rangle$ 放電電荷量 $\boldsymbol{Q}_{d}$ と空間電荷量 $\boldsymbol{Q}_{s}$ の関係}

印加電圧，すなわち棒電極の電压（以下，V1 と記 す）が比較的低く，コロナがギャップを橋絡しない条 件では，コロナ放電によりギャップ中に放出される放 電電荷量 $Q_{d}$ とギャップ中に存在する空間電荷量 $Q$ s は等洒であり，またこれらはプロープP，の誘導電荷 $q_{3}$ に比例する(4)。乙れに対し，印加電圧 $V_{1}$ を堌大 させると上述の比例関係が成立せず，(3)式より求ま る $Q_{s}$ は $Q_{a}$ に対して飽和の傾向を示す。ここでは, この飽和領域における $Q_{a} \subset Q_{s}$ の関係に関する実験 結果について述べる。

実験はギャップの長さ $g$ を $5 \sim 15 \mathrm{~cm}$ とし，V1は コロナ開始電在 $V_{\text {on }}$ から 50\% フラッシオーバ電压 $V_{50}$ まで変化させた。 $V_{1}$ を次第に増大する上, コロナ はギャップを橋絡する。このような電圧を，ここでは $V_{b s}$ と呼ふ。 $V_{o n}, V_{b s}$ および $V_{50}$ 上gの関係を园 3 に示す。とれらの関係曲線は文献 $(4)$ 上同じである。 


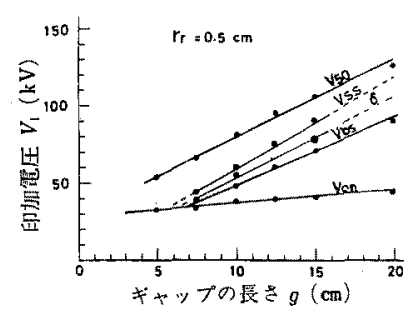

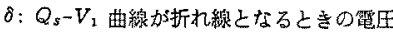

$V_{s s}:$ 二次ストリーマ発生汇必要洂電压

図 35 種の特性電圧とギャップの長さの関係

Fig. 3. Relations between 5 characteristic voltages and the gap length.

まず，印加電圧 $V$ とと $Q_{s}$ および $Q_{a}$ の関係をギャ ップの長さ $g$ をパラメータとして求めた実験結果が 図4である。(a)図は $Q_{s}-V_{1}$ 曲線，(b)図は $Q_{d}-V_{1}$ 曲線である。（a）図のように，各ギャップの長さ $g$ に 扣けるQsは $V_{1}$ の増大に伴って指数関数的に増加す る。また，本実験における $g$ の最小值 $5 \mathrm{~cm}$ の場合を 除くと, $g$ が $7.5,10$ および $15 \mathrm{~cm}$ では， $Q_{s}-V_{1}$ 曲 線が折れ線となる。このときの電圧は，前述の $V_{b s}$ よ りも約 $20 \%$ 程度高い電圧であり, $g$ が $7.5,10,15 \mathrm{~cm}$ に対して，それぞれ約 $40,55,72 \mathrm{kV}$ である。各ギャ ップの長さに対するこれらの電生をすの記号で表わ し，因 $3 に \delta-g$ 曲線を図示する。なお $g$ が $5 \mathrm{~cm}$ で は，図3のように測定可能な $V_{0 n}$, 測定加困難な $V_{b s}$ と反が混在するので $V_{o n} \geqq \delta$ となされる。

図 4(b)の $Q_{d}-V_{1}$ 曲線は， $Q_{d}$ が $V_{1}$ の増大行従二 てほぼ指数関数的に增加することを示していて， $Q_{s}-$ $V_{1}$ 曲線のように折れ線が存在しない。また，同図に は平板電極加ら大地汇流出する電荷 $Q_{d^{\prime}}$ を(2)式よ り求めて破線で示した。ての $Q_{d}{ }^{\prime}-V_{1}$ 曲線は $Q_{d}-V_{1}$ 曲線之同様に直線で示され，各ギャップの長さとむ両 曲線は並行していて $Q_{d}{ }^{\prime}$ は $Q_{d}$ より小さい。その理 由は，(2)式の電流 $i_{2}$ が主に静電誘導による電流で あるためであり，文献(2)に述べられている。

$Q_{s}-V_{1}$ 曲線の実験式老 4 (a) 加ら求めると次式 となる。

$$
Q_{s}=S_{a} \exp \left(S_{b} V_{1}\right)
$$

こてに，S。は片対数グラフにおける直線の傾斜を表 わす係数であり， $S_{a}$ はこの直線が緶軸 ( $Q s$ 軸) 乙交 わるときのQs の值である。 $S_{a}, S_{b}$ の值を $V_{1} \leq \delta$ の 領域之 $V_{1}>\delta$ の領域とで，そ记ぞれ各ギャップの長 さごとに示すと表1のと斿りである。

同様 $儿 ， Q_{d}-V_{1}$ 曲線の実験式老図 $4(\mathrm{~b})$ 加求为 ると次式となる。

$$
Q_{d}=S_{c} \exp \left(S_{d} V_{1}\right)
$$

昭 $57-7$

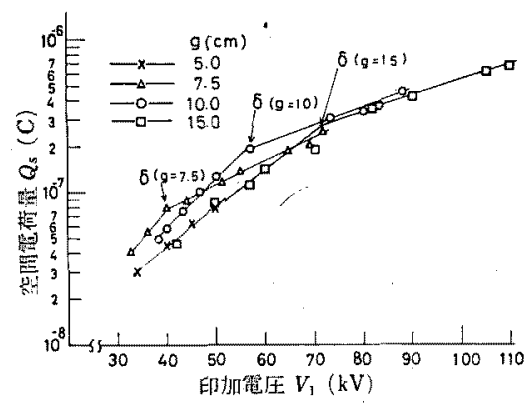

(a) $Q_{s}-V_{1}$ 曲線

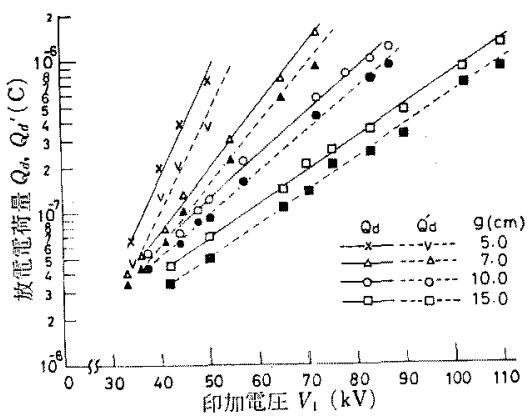

(b) $Q_{d}-V_{1}$ 曲悢

図 4 空間電何量 $Q_{s}$, 放電電荷量 $Q_{t}$ 之 印加堂圧 $V_{1}$ の関係

Fig 4. Relation of $Q_{s}$ and $Q_{d}$ vs. applied voltage $V_{1}$.

表 1 実験式中の係数 $S_{a} \sim S_{d}$ の值

Table 1. The coefficients $S_{a} \sim S_{d}$ used in the empirical formulas.

\begin{tabular}{c|c|c|c|c|c|c}
\hline \multirow{2}{*}{$g$} & \multicolumn{2}{|c|}{$S_{a}\left(\times 10^{-9}\right)$} & \multicolumn{2}{c|}{$S_{b}\left(\times 10^{-3}\right)$} & $S_{c}\left(\times 10^{-9}\right)$ & $S_{d}\left(\times 10^{-3}\right)$ \\
\cline { 2 - 7 }$(\mathrm{cm})$ & $V_{0 n} \leqq V_{1}$ & $V_{1}>\delta$ & $V_{0 n} \leqq V_{1}$ & $V_{1}>8$ & $V_{1} \geqq V_{0 n}$ & $V_{1 \geq V_{c n}}$ \\
\hline 5 & & 3.7 & & 0.060 & 0.4 & 0.150 \\
7.5 & 2.2 & 14.5 & 0.090 & 0.040 & 2.2 & 0.090 \\
10 & 4.9 & 31.0 & 0.064 & 0.030 & 4.7 & 0.065 \\
15 & 3.7 & 66.0 & 0.060 & 0.023 & 3.6 & 0.060 \\
\hline
\end{tabular}

単位: $S_{a}, S_{v} ; \mathrm{C}, S_{b}, S_{d} ; \mathrm{V}^{-1}$

ただし，(5)式の場合上同様に， $S_{d}$ は直線の傾斜を 表わす係数で， $S_{c}$ はこの直線が $Q_{d}$ 軸と交放るとき の $Q_{d}$ の值である。 $S_{c}$ と $S_{d}$ の值を各ギャップの長 さごとに表1汇示す。

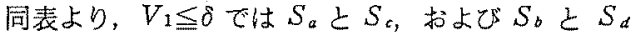
の值がそれぞれはぼ致するので，(5)式上(6)式か ら $Q_{s} \fallingdotseq Q_{d}$ 加得られる。また， $V_{1}>\delta$ では両式加ら $Q s$ 之 $Q_{d}$ の次の関係式が得られる。

$$
Q_{s}=S_{a}\left(Q_{d} / S_{c}\right) S_{b} / S_{d}\left(V_{1}>\delta\right) .
$$

$Q_{s}$ と $Q_{d}$ の関係図 $4(\mathrm{a}),(\mathrm{b})$ 加ら求めて图 5 に示す。また，同図には（7)式の実験式を基にした計 


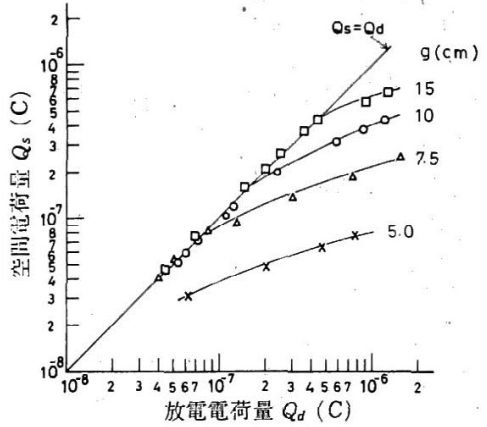

図 5 Q $Q_{s}$ と $Q_{d}$ の関係

Fig. 5. Relation of $Q_{s}$ vs. $Q_{d}$.

算結果を実線で示す。同図より， $g$ が $7.5,10,15 \mathrm{~cm}$ に対し， $Q_{d}$ 吕そ机ぞれ約 $8 \times 10^{-8} ， 2 \times 10^{-7}$ および $4 \times 10^{-7} \mathrm{C}$ となるまでの簌囲では $Q_{s} \fallingdotseq Q_{d}$ である。 前述により， $V_{1} \leqq \delta$ のときにての関係が得られる。 しかし， $V_{1}$ が $\delta$ を超過し， $Q_{d}$ が上記の值を超え ると $Q_{d} \fallingdotseq Q_{s}$ の直線関係がなくなり，図のようにギ 中ップの長さに対して，それぞれの飽和特性をもつ

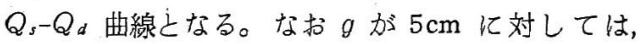
前述のように $V_{\text {on }}$ ठ $-Q_{d}$ 曲線は飽和領域のみとなる。

\section{〈3.2〉 コロナ放電の進展上空問電荷の発生}

ここでは，コロナ放電による空間電荷の発生過程を 述へ， $Q_{s}-Q_{d}$ 曲線の飽和特性について説明する。

すなわち，例をギャップの長さ $10 \mathrm{~cm}$ の場合にと り, その場合の棒電極の電流 $i_{d}$, 平板電極の電流 $i_{2}$, プローブ $P_{r}$ の電流 $i_{3}$ ，ギャップ軸 $(z$ 軸) に添う各 位置の光パルスおよび静止写真を測定し，図示したの が図6である。同図 $(\mathrm{a}),(\mathrm{b})$ はそれぞれ印加電圧 $V_{1}$ が $V_{1}<\delta$ および $V_{1}>\delta$ におりる測定結果である。両 図の $i_{d}, i_{2}, i_{3}$ 捛よび光パルスは，それぞ机同一の印加 電圧で 4 5 回繰返して测定したオシログラフであ り，コロナ放電は電圧を 1 回印加するたびに 1 回発生 する。同図(a-2) および (a-3)の光パルスおよび静止写 真加ら，コロナは時刻 $t=t_{0}$ 亿棒電極先端 $(z=10 \mathrm{~cm})$ で発生し, 平均して $350 \mathrm{~ns}$ 後に平板電極上 $z=2.5 \mathrm{~cm}$ に達し，その位置で停止している。こてでは，てのよ うなコロナを正コロナストリーマ PS と呼ぶ。 PS の 進展速度は約 $2.7 \times 10^{7} \mathrm{~cm} / \mathrm{s}$ となる。また, 同図(a-1) の $i_{d}, i_{2}$ および $i_{3}$ はいずれも時刻 $t_{0}$ において立上 り，ピークを経て単調に減衰して約 $350 \mathrm{~ns}$ 後には零 となる。これらの電流波形の立上りは，同図のように ほぼ相似形である。これらの電流の継続時間之, 光パ ルスから見た PS の進展期間吕上述のように一致す

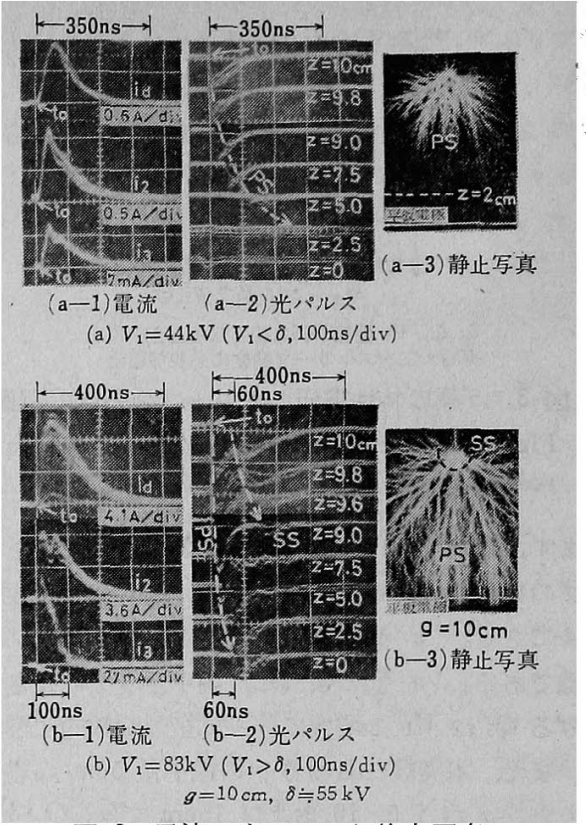

図 6 電流, 光パルス上静止写真

Fig. 6. Oscillograms of currents and light pulses, and photographs of the corona.

るととから, 空間電荷はほぽ PS の進展中にのみ生成 されるとみなされる。

図6(b) は $V_{1}$ が $83 \mathrm{kV}$ のときの例で，乙の電圧 はギャップの長さが $10 \mathrm{~cm}$ に対して $V_{50}$ にほほ等し い電圧である。同図(b-2), (b-3) の光パルス拉よび静 止写真から, PS は時刻 $t_{0}$ より約 $60 \mathrm{~ns}$ 後にギャップ を槁絡しているので, その平均の進展速度は約 $1.7 \times$ $10^{8} \mathrm{~cm} / \mathrm{s}$ である。同図( $\left.\mathrm{b}-1\right) の i_{d}$ と $i_{2}$ を比較する と，その波形はほぼ相似形である。乙れに対して $i_{d}$ 之 $i_{3}$ では， $i_{d}$ に比して $i_{3}$ の立下りが急であり， $i_{a}$ 加時刻 $t_{0}$ 加ら約 $400 \mathrm{~ns}$ 後に零之なるのに対して， $i_{3}$ はPSがギャップを橋絡した後の $t_{0}$ から約 $100 \mathrm{~ns}$ 後に ほぼ零となる。この上うに，両者の間䎲約 $300 \mathrm{~ns}$ の 時間差があり， $V_{1} \leqq \delta$ の条件下の上うに $i_{d}$ と $i_{3}$ の波 形の相似性が成立しない。乙れらの $i_{d}, i_{3}$ 加ら(1) 式 を用いて求めた $Q_{d}$ は約 $1 \times 10^{-6} \mathrm{C} ，(3)$ 式を用いて 求めた $Q_{s}$ は約 $3.5 \times 10^{-7} \mathrm{C}$ であるので $Q_{d}>Q_{s}$ とな り, $V_{1} \leqq \delta$ の条件下のように $Q_{d} \fallingdotseq Q_{\text {s }}$ とはならない。 $V_{1}>\delta$ の条件下で， $V_{1}$ を增大するとi 9 立下りが より急になり， $i_{d}$ と $i_{3}$ が零になるまでの両者の時間 差屯增大するので，Qa は Qs に比べてより大きくな る。従って, $V_{1}>\delta$ の条件下では, 図 5 に示したよう にQs は $Q_{a}$ に対して直線関係が成立しなくなる。

なお，図6(b-2) の光パルスに見られるように，棒 
電極の先端部 $(z \simeq 9 \sim 10 \mathrm{~cm}$ の範囲) では PS の発光 の後に第 2 の光パルスが観測される。すなわち，との 光パルスは PS がギャップを橋絡した時刻之ほぼ同時 刻汇棒電極先端 $(z=10 \mathrm{~cm})$ で始まり, PS の進展速 度より約 1 けた小さい速度, 約 $1.3 \times 10^{7} \mathrm{~cm} / \mathrm{s}$ |でギャ ップ中に進展する。また，第 2 の光パルスは，同図 (b-1)の $i_{d}$ との比較から， $9.6 \leqq z \leqq 10 \mathrm{~cm}$ ではほぼ $i_{d}$ が零となるまで継続し，またこの期間で $i_{3}$ がほほ 零となっている。このような光パルスは，PS の経路 の再発光現象で, 呉氏 ${ }^{(6)}$ ，伊佐氏(7)らに上り二次ス卜 リーマ（以下，SS と記す）之称されているむのであ り, ここであとの呼称を用いる。SS の発生に必要な 印加電圧を $V_{\text {ss }}$ とすると， $V_{\text {ss }}$ は $\delta$ より高く，図 3 に示すようにギャップの長さ $g$ の增大と共に增す。 $\langle 4 \cdot 1\rangle$ 節で詳述するように，SS の進展期間では空間 電荷の中和現象が起こり，SS の発生はこの中和現象 之関係がある。

\section{〈3.3〉 平板電極表面の電界亡空間電荷について}

平板電極表面の電界は, Collins 氏引によって測定さ れ，その詳細が発表されている(1)。本論文では，図2 亿示す平板電極表面の電界測定用プローブ $P_{E 1} \sim P_{E 8}$ で測定される電界のうち，コロナ放電の空間電荷によ る電界とプローブ $P_{r}$ で測定した空間電荷 $Q s$ の関係 について考察する。本実験伅用いた電圧の波形は, $+(0.6 \times 40) \mu \mathrm{S}$ であり, ギャップの長さ $g$ は $10 \mathrm{~cm}$ で ある。

図 7 は平板電極の中心，すなわち棒電極直下に置か れたプローブ $P_{E 1}$ の表面電界の測定例である。(a) 図快PS がギャップを橋絡し得ないような印加電圧 $V_{1}\left(=40 \mathrm{kV}<V_{b s}\right)$ に求ける電界，(b)図は橋絡する ような $V_{1}\left(=50 \mathrm{kV}>V_{b s}\right)$ における電界である。(a) 図では電圧印加後約 $2 \mu \mathrm{s}$ の時刻 $t_{0} に$ PS が発生して いる。そのときの表面電界は約 $1.1 \mathrm{kV} / \mathrm{cm}$ であり, ての静電界を以下では $E_{V}$ とする。また， $t_{0}$ から約 $350 \mathrm{~ns}$ 後に $P_{E 1}$ の電界は空間電荷によって約 $3 \mathrm{kV} /$ $\mathrm{cm}$ よなり， $E_{V}$ より約 $1.9 \mathrm{kV} / \mathrm{cm}$ 高くなる。なお， 光パルスの測定に上机ば, PS は時刻 $t_{0}$ から約 $350 \mathrm{~ns}$

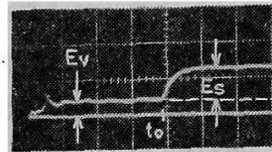

(a) $V_{1}=40 \mathrm{kV}$

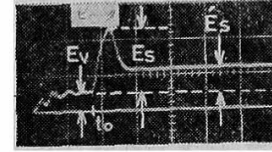

(b) $V_{1}=50 \mathrm{kV}$ $(2.5 \mathrm{kV} / \mathrm{cm} / \mathrm{div}, 500 \mathrm{~ns} / \mathrm{div})$
図 7 平板電極表面の電界波形

Fig. 7. Oscillograms of the electric field on the plane.
の間に平板電極上約 $4 \mathrm{~cm}$ に到達する。図示のように， 空間電荷のみによる電界を $E s$ とすると, 表面電界 $E$ は $E=E_{V}+E_{s}$ で表わされる。 $E_{V}$ は印加電圧に比例 する電界である。（b)図では，PS 発生時刻 $t_{0}$ から 約 $250 \mathrm{~ns}$ 後に表面電界が約 $6 \mathrm{kV} / \mathrm{cm}$ のピーク值をと り，その後約 $200 \mathrm{~ns}$ 後には約 $3 \mathrm{kV} / \mathrm{cm}$ に低下し，そ の值が保持されている。な拉，光パルスの測定結果か ら， $t_{0}$ から表面電界のピークに至る期間に PS は平 板電極上約 $1.5 \mathrm{~cm}$ に到達する。図示のように，ピー ク值に達した後の空間電荷による電界は $E s$ 之区別す るために $E_{s}{ }^{\prime}$ の記号で表わし，乙の場合の表面電界 を $E^{\prime}$ とすると $E^{\prime}=E_{V}+E_{s^{\prime}}$ となる。また，ピーク 值は（a）図之同様に $E$ で表利。このように， $V_{1}>$ $V_{b s}$ の条件では PS 発生時の電界はピーク值 $E$ から $E^{\prime}$ へ低下するが，てれはPS によって生成された空 間電荷の一部が中和されるためと考えられている(1)。 これについては $\langle 4 \cdot 1\rangle$ 節に考察する。

さて，図6の静止写真任見られるような PS の枝が 直接プローブ $P_{E}$ に当たる之, 電荷がそのプローブに 流入するので, 電界は上述の測定電界より 10 倍程度 の高い電界となる。本実験では，てのような実験ケー スは除外した。

図8は $V_{1}$ をパラメータとして， Es と $E_{s}^{\prime}$ の棒電 極直下からの距離 $r$ に対する関係を示したあのであ る。 $V_{1} \geqq 50 \mathrm{kV}$ の条件では $E_{s}-r$ 曲線と $E_{s^{\prime}}-r$ 曲線 が描加れる。乙の之きの $E_{s}$ は図7(b) 亿示すよう 亿, 表面電界のピーク值 $E$ 之静電界 $E_{V}$ の差であ る。図8加ら， $E_{s}$ 斿よび $E_{s}{ }^{\prime}$ は $V_{1}$ の增加之共に增 すが，てれについては図9で述べる。Esは，図8の ように $r$ の増大と共に単調に減少する。その減少の割 合は，例えば $V_{1}$ が $40 \mathrm{kV}$ では， $r=0$ で $E_{s}$ が 1.9 $\mathrm{kV} / \mathrm{cm}, r=14 \mathrm{~cm}$ では約 $0.2 \mathrm{kV} / \mathrm{cm}$ であるので約 $90 \%$ である。これに対して，同じ位置における $E_{V}$ の

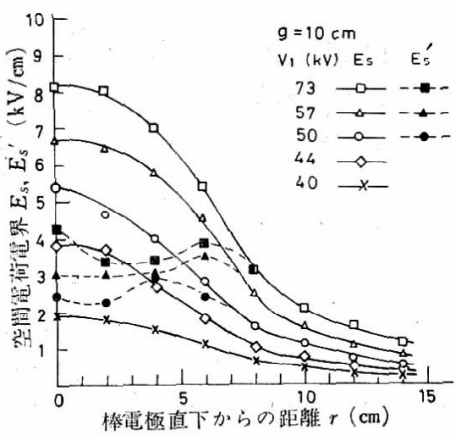

図 8 空間電荷電界 $E_{s}, E_{s}^{\prime}$ の分布

Fig. 8. Distributions of electric fleld on the plane caused by space charge. 


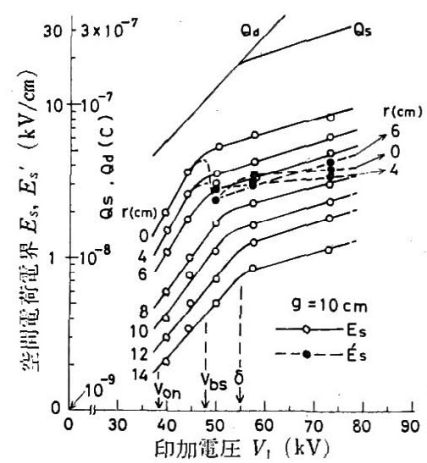

図 $9 E_{s}, E_{s}{ }^{\prime}$ と $V_{1}$ の関係

Fig. 9. Relation of $E_{s}, E_{s}{ }^{\prime}$ vs. $V_{1}$.

減少の割合は，実験によると約 $35 \%$ であるので， $E$ s の $r$ に対する減衰は大きい。次に， $E_{s}{ }^{\prime}-r$ 曲線は同図 に示すように, その変化が複雑で平板電極の中心部で はむしろ低い值をとるが， $r \gtrsim 8 \mathrm{~cm}$ では $E_{s-r}$ 曲線に 一致する。

図9は $E_{s}$ および $E_{s}{ }^{\prime}$ と $V_{1}$ に関する曲線であり， $r$ がパラメータとなっている。図 8 の実験結果から, $r<8 \mathrm{~cm}$ では $E_{s}-V_{1}, E_{s}{ }^{\prime}-V_{1}$ 曲線が描かれ, $r \gtrsim 8$ $\mathrm{cm}$ では $E_{s}-V_{1}$ 曲線が描かれる。同図のように， $E_{s}$ $-V_{1}$ 曲線は，図 $4(\mathrm{a})$ より転載した $Q_{s}-V_{1}$ 曲線と同 様に指数関数的に増加し折れ線となり，また曲線の傾 斜は画曲線でほぼ一致する。 $E_{s}-V_{1}$ 曲線が折れ線と なる電圧 $V_{1}$ は，図のように $r$ が大きくなるほど高 くなり，r=0 ではほぼ $V_{b s}(\fallingdotseq 48 \mathrm{kV})$ 亿等しく, $r \geqq$

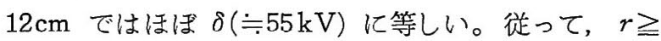
$12 \mathrm{~cm}$ では $E_{s}-V_{1}$ 曲線と $Q_{s}-V_{1}$ 曲線とほぼ平行と なる。なお $E_{s}{ }^{\prime}-V_{1}$ 曲線では， $Q_{s}-V_{1}$ 曲線に比べ て折れ線となった後の曲線の傾斜が小さいので，両曲 線は平行したすのではない。

\section{4. 考察}

〈4·1〉PS により生成される空間電荷の中和につ いて 図7(b)において, $V_{1}>V_{b s}$ の条件では PS 発生時の平板電極の表面電界がピーク值 $E\left(E_{V}+E_{s}\right)$ 加ら $E^{\prime}\left(E_{v}+E_{s^{\prime}}\right)$ 一低下するのは，PSにより生成さ れた空間電荷の一部が中和されるためと述べたが，こ のことについて考察を加える。

いま，空間電荷の中和に関する実験として，図 10 中に示すように，ギャップ軸之垂直に絶縁板を置いた 状態で棒電極に電圧を印加し，平板電極の表面電界 $E$ を測定した。なお，絶縁板は 1 回どとに取替えた。 図 10 は印加電圧 $V_{1}$ をパラメータとし, 棒電極直下 $(r=0)$ における $E$ と絶縁板の高さ $h_{a}$ (図参照) の関

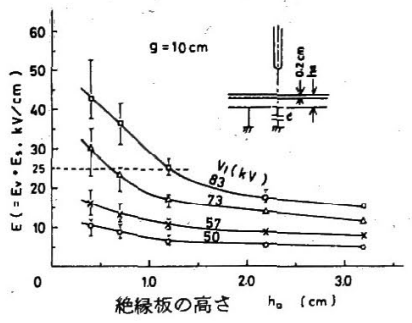

図 10 絶縁板の高さ $h_{a}$ に対する 表面電界 $E$ の変化

Fig. 10. Variation of the electric field $E$ with the height of the insulating barrier.

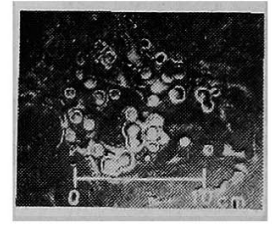

（d）電荷図（下面）

（C）負䨌荷図の数的とhaの関保

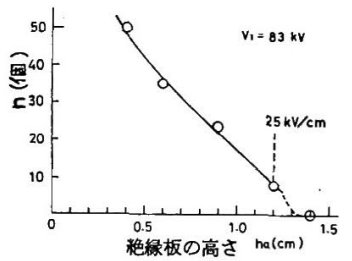

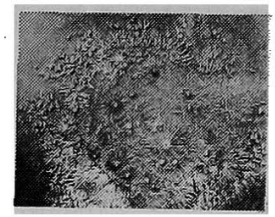

（b）電荷図（上面）

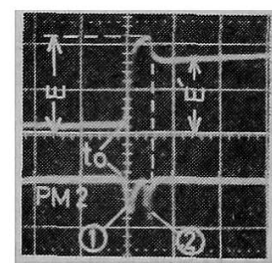

$\left(E: 13 \mathrm{kV} / \mathrm{cm}, \mathrm{PM}_{2} ; \mathrm{z}=\right.$

$0.5 \mathrm{~cm}, h_{a}=1.2 \mathrm{~cm}, 500 \mathrm{~ns} / \mathrm{div}$ )

(d) 電界, 光八刀又波形
図 11 負ストリーマ NS の発生に関する 実験結果

Fig. 11. Experimental results on the occurence of negative streamer.

係を示したものである。この実験で，絶縁板の下面 （平板電極に対向した面）では，図 11 (a)に示すよう. な負の電荷図が得られた。また，絶縁板の上面では同 図(b)のように, PS による正の電荷図が得られた。 負電荷図は直径約 $0.5 \sim 2.5 \mathrm{~cm}$ の円形であり，実験 上の観測からは, 主に棒電極からの PS と絶縁板との 交点の下面に生じる ${ }^{(8)}$ 。その数 $n$ は, 同図( $\mathrm{c}$ ) に示 すように， $V_{1}$ が $83 \mathrm{kV}$ のときでは $h_{a}>1.2 \mathrm{~cm}$ でほ ぼ零となる。 $h_{a} \leqq 1.2 \mathrm{~cm}$ では，図 10 加表面電界 が $25 \mathrm{kV} / \mathrm{cm}$ 以上となっているので, 負電荷図は 25 $\mathrm{kV} / \mathrm{cm}$ 以上の電界で生じる。 $V_{I}$ が $73 \mathrm{kV}$ の場合に も $h_{a} \leqq 0.6 \mathrm{~cm}$ で同様の電界となる。また， $V_{1} \leqq 57 \mathrm{kV}$ では電界は $25 \mathrm{kV} / \mathrm{cm}$ に達しておらず，真の電荷図は 得られなかった。このような高電界は，PSによって 棒電極と絶縁板の間および絶縁板の表面に空間電荷が. 
生成されたためである。

負電荷図の発生時には図 11 (d) に示すように, 表 面電界の波形に電界低下が観測された。実験では電界 $E$ から $E^{\prime}$ への低下は $h_{a}$ が大なるほど小さくて, 同 図 $\left(h_{a}=1.2 \mathrm{~cm}\right)$ では $E \fallingdotseq 25 \mathrm{kV} / \mathrm{cm}, E^{\prime} \fallingdotseq 18 \mathrm{kV} / \mathrm{cm}$ となっている。なお, $h_{a}=0.6 \mathrm{~cm}$ では $E \fallingdotseq 37 \mathrm{kV} / \mathrm{cm}$, $E^{\prime} \fallingdotseq 10 \mathrm{kV} / \mathrm{cm}$ であった。また，絶縁板と平板電極間 の光パルスでは，同図(c)のように電界低下時に合致 する放電光が得られた。図示の光パルス (1)は, PSに よる発光の絶縁板表面などからの反射光で, PS 発生 時刻 $t_{0}$ に一致し，(2) が放電光である。これらの実験 結果加ら，負電荷図の発生は PS による空間電荷の効 果で絶縁板と平板電極との間に負コロナストリーマ (以下，NSと記す）が生じたためである。このような 条件下での NSの発生については Nasser 氏のリヒテ ンベルグ図による研究で述べてある(8)。これらのこと から，平板電極の表面電界の低下現象はNSによる負 電荷発生亡関係がある。

なお，図8の $E_{s}-r$ 曲線から，絶縁板がない場合に は，静電界 $E_{V}$ を考慮に入れても上述の $25 \mathrm{kV} / \mathrm{cm}$ よ り低い約 $10 \mathrm{kV} / \mathrm{cm}$ 以下の電界で NS が発生し, 電 界の低下現象が生じるととになるが，これは平板電極 の表面の電界が PS の進展に伴って上昇する途中に NS が発生したためと考えられる。

いま，絶縁板がない状態で PS が発生し，その空間 電荷効果によって NS が発生すると，PS による正電 荷群は NS による負電荷群により中和されて減少す る。この様子を電荷図の観測により示したのが図 12 である。この電荷図の観測には，同図中に示すように ギャップ軸と平行および垂直な絶縁板（㘝中，それぞ れ (1), (2) と記す) を用いた。（a ）（c）図は，絶縁板 (2) 除いて $h_{a}=0$ とし, 印加電圧 $V_{1}$ を変えて絶縁 板 (1)で得られる電荷図の変化を示していて，図に見 られるように棒電極から枝状に正電荷が残留してい る。(b), (c)図では, PS は絶縁板に沿って平板電極 まで到達しており，その PS の枝では正電荷が残留せ ず，（b)図に示すようにむしろ比較的微量の負電荷が 残留する。乙れは，PS の正電荷が NS の負電荷で中 和されたことを示すむので， $V_{1}$ の増大に従ってこの ような中和現象が多く見られる。(c)図では, ギャッ プ軸からの距離が大きい位置では正電荷図が得られる が、ギャップ軸に近い位置では，電荷の少ない中和領 域となっている。なお，(d)図は絶縁板 (1) の下に (2) をそう入したときの電荷図で，ての場合は，絶縁板 (2) によって中和が防げられるので，ギャップ軸に近い位 置でも正電荷図が得られた。

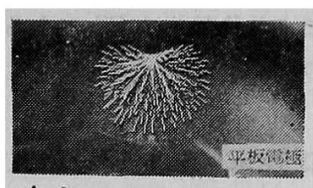

(a) $V_{1}=40 \mathrm{kV}, h_{a}=0$

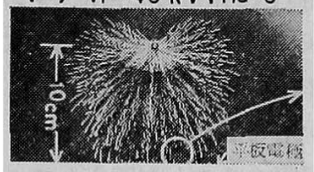

(b) $V_{1}=57 \mathrm{kV}, h_{a}=0$

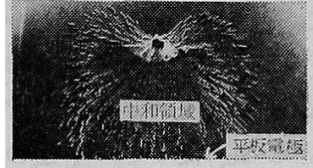

(c) $V_{1}=73 \mathrm{kV}, \mathrm{ha}_{\mathrm{a}}=0$

(d) $V_{1}=73 \mathrm{kV}, h a=1.2 \mathrm{~cm}$

図 $12 V_{1}$ の違いによる電荷図の変化 (絶縁板 (1) の電荷図)

Fig. 12. Variation of the dust figure with $V_{\mathbf{1}}$.

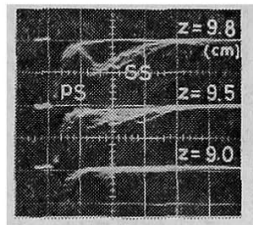

(a) $\mathrm{ha}=0.2 \mathrm{~cm}$ $1 \mathrm{~g}=10 \mathrm{~cm}$

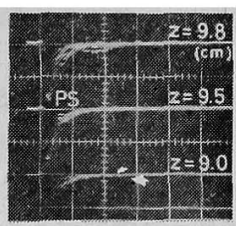

(b) $\mathrm{ha}=1.2 \mathrm{~cm}$
図 $13 h_{a}$ の違いによる光波形の変化

Fig. Variation of light pulses with the height of the insulating barrier.

さて, $\langle 3 \cdot 3\rangle$ 節の図 6(b-2)において, 二次ストリー マ SS の発生に上述の中和現象が関係すると述べた。 てれについては次のような実験によって考察した。図 13 は絶縁板 (1)を除いて (2)のみとし，棒電極先端部 $(z=9.0 \sim 9.8 \mathrm{~cm})$ の光パルスを測定した結果で, $(a)$, (b)図はそれぞれ $h_{a}$ が $0.2 \mathrm{~cm}$ および $1.2 \mathrm{~cm}$ であ る。（a）図では，絶縁板がないときの測定結果〔(図 6 (b-2)] のように SS の光パルスが見られるが, (b)図 では，このパルスはほとんど消えて PS の光パルスの みとなっている。(a)図で絶縁板 (2) が存在するにも かかわらず SS が生じるが，乙れは絶縁板より上部で む中和現象が生じるためであり，この場合の中和現象 は絶縁板 (2)の上に (1)を置いて, その電荷図より観測 できた。また， $h_{a}$ が $1.2 \mathrm{~cm}$ の場合の電荷図は図 12 (d)であり，既に述べたように中和現象は抑制されて いる。以上の考察加ら, SS は中和現象に伴って発生 するとみなされる。

以上のように, PS の発生によって正の空間電荷が 生成され，その空間電荷効果によって平板電極上で 
NS が発生する。とのNSによる負露荷は PSに上る 正電荷の一部和し，この中和現象が SS の発生に 影響する。

〈4.2〉 $\boldsymbol{Q}_{s}-\boldsymbol{Q}_{d}$ 曲線の飽和特性について 図6で 述べなよう，SS の進展期間では棒電極の䉓流 $i_{d}$ の みが流れて，プロープP，の電流访ほはほ雾とな る。従って, SSD進展期間に $Q_{s}$ と $Q_{d}$ の差が生じ, 図4のQ $Q_{s}-Q_{d}$ の飽和特性が生じることになるので， この飽和特性が中和現象佂起因するととが明らかであ る。以下，とのことについて考察する。

文嗝(4)で述べたようにギャップにグロ一放電が 形成される上，分割電極にはその電流が流れるが，プ ロープPrの誘導電流牥零亡なる。徉って，上述の SS 進展中の $i_{d}$ とis の関倸は, 丁度, このグロー放 電時の両電流の関係となっている。ただし，本論文で 述べたコロナ放電では，PSにより生成される正電荷 そNSによる負電荷とが，それぞれプロープP $P_{r}$ に 対して極性の相異なる誘導電流を生じさせ, この両電 流が互い儿打占消し合った結果，洸が見かけ上零とな ったものである。なお，SS 進展中の PS の正電荷亡 は図12(c) の電荷図に見みられるように, ギャップ 軸からの距漓倠が大きい位置で発生し，中和されずにそ の場に残留する電荷である。との位置では，ギャップ 軸に沿う電界に比して弱電界であるので，その弱電界 中を比較的低速度で進展するPSに上ってNS 発生後

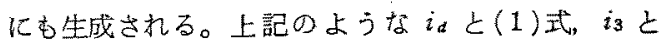
(3)式炕りそれぞれ求まる $Q_{d}$ 招よび $Q_{s}$ は，SS 進展中に中和される正電荷分だけQ，のはうが少なく なり， $Q_{s}-Q_{d}$ 曲線の飽和特性が生じる。

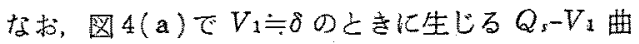
線の折机曲りについてむ，上記と同様に中和現象の影 㗽によるすのであり，またてのようなQ、により生じ た平板電極の表面電界江関守る $E_{s}-V_{1}$ 曲線は，図9 のように折楾となる。

\section{5.むすび}

大気中・棒対平板電極江正極性雷インパルス電圧を 印加したときのコロナ放電による空間電荷の振舞を，
コロナ放電の進展過程と関連つけて説明した。得られ た結果を以下に要約する。

（1）コロナ放電は正コロナストリーマPS 加負 コロナストリーマ NS, 更に二次ストリーマSSへと 進展する。

（2）PSによって生成された正空間電荷の効果で NS が発生して負電荷が生成され，PSに上る正空間 電荷を中和する。また，SS はこの中和現象の過程で 発生する。

（3）コロナ放電による空間電荷量は，中和現象の ために放電電荷量の增大に対して飽和の傾向をむつ。

（4）放電電荷量および空間電荷量対印加霓圧の関 係曲線は、それぞれ指数関数で近似できる。両曲線は 中和現象が発生するまででは一致するが，中和現象が 発生するとその影響で空間電荷量対印加電圧の曲線の 傾斜が小さくなる。

最後に，本研究の遂行にあたり有益な助言をいただ いた本学林 宗明教授, 伊佐 弘助手に深謝の意を表 します。また，本研究に協力された大学院生広岡康彦 氏（現，大阪市交通局勤務）に感謝いたします。 (昭和 56 年 9 月 16 日受付, 同 57 年 2 月 15 日再受付)

\section{文 献}

(1) M. M.C. Collins \& J.M. Meek: "Measutement of Field Changes Preceding Impulse Breakdown of Rod-Plane Gaps", Proc. 7 th Int. Conf. Ionization Phenomena in Ionized Gases, 1, 581 (1966)

(2) E.M. Bazelyan: "Measurement of Space Charges in the Initial Stage of a Positive Long Spark", Sotriet Phys. Tech. Phys., 9, 3, 370 (1964)

(3) R. T. Waters, T. E. S. Rickard \& W. B. Stark; "Electric. field and current density in the impulse corona discharge in a rod/plane gap", Proc, Roy. Soc, A-304, 187 (1968)

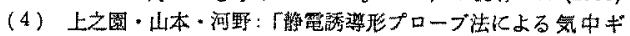

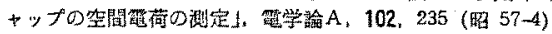

(5) Y. Toriyama: Dust Figure of Surface Discharge and its Applications (1961) Kinokuniya

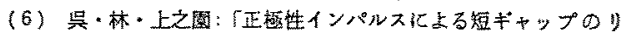

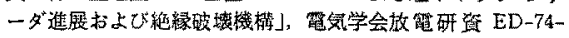
15 (19 49)

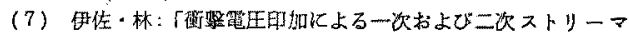

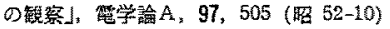

(8) E. Nasser: "Role of the Cathode Field Emission in the Streamer-Spark Transition", J. Appl. Phys., 37, 13(1966) 